\title{
User Interface and User Experience Design of Family Intervention Application for Parents of Children with Autism
}

\author{
Luqyana D. Amira ${ }^{1, *}$ Wagino Wagino ${ }^{1,}$ I K. Budayasa ${ }^{1}$ \\ ${ }^{1}$ Universitas Negeri Surabaya \\ *Corresponding author. Email: luqyanadhiya22@gmail.com
}

\begin{abstract}
Children with autism need optimal and consistent intervention at school and home. Parents need an application as a guide for implementing interventions at home. This study aims to develop a home-based intervention application design so that it is easy to use by parents and match with the intervention needs of children with autism. This research method is design thinking. Several steps of the design thinking method are empathy, define, ideate, prototype, and test. The test through usability testing using the Maze platform, 93\% results were obtained. Then in data analysis using a usability test questionnaire, the learnability aspect was obtained $90 \%$ and the memorability aspect was obtained $80 \%$. The whole test shows good and successful results, so the prototype can be continued on the implementation of the application.
\end{abstract}

Keywords: Autism, Applications, Home Intervention, Family Intervention, User Interface.

\section{INTRODUCTION}

Children with autism have barriers in several aspects, communication, behavior, and social. Autistic children withdraw from the social environment, have communication disorders, and have repetitive behavior [1]. Autism should be given intervention of behavior modification in order to minimize children's barriers, such as communication, behavior, and social and can carry out daily activities [2].

Currently, the provision of interventions for autism is experiencing difficulties. The pandemic situation resulted in children not getting intervention. Families with children with autism have difficulties because schools and services are closed. The COVID-19 pandemic affects children's mental and emotional health [3].

The absence of intervention received by students during the Covid-19 pandemic resulted in autistic behavioral problems appearing more often [4]. In addition, families also feel stressed due to the pandemic because they have to care for and provide interventions for children for 24 hours, longer than the usual time [5].
Based on the preliminary studies that have been done, parents say that there are many behavioral regressions. Parents said that previous interventions were futile because there were many setbacks. Behavioral regression experienced by autistic children is caused by inconsistency of intervention. So, parents have an immense role in providing interventions [6].

According to [7], parents are the closest people to optimizing interventions in autism. One of the requirements to be able to implement interventions at home properly is parental knowledge about the procedures for implementing interventions [6].

Parents' perceptions of how difficult to implement interventions at home must be changed. The implementation of interventions at home can be integrated with simple daily activities. In addition, family interventions improve social interaction skills in autism [8]. Research also shows that subjects experienced increased social interaction and reduced risk of autism [8]. Then, according to [9] parentcentered intervention showed effective results. It was further explained that the need for further research on the role of parents as an intervention model. Parents have a role in preparing and involving themselves in 
child interventions and planning family-centered treatment or interventions [10].

Based on this, educational media is needed to increase parents' understanding of providing interventions for children, so the implementation of interventions at home is structured and in accordance with children's needs, making it easier for families to implement interventions at home. Education through gadgets with educational applications is the right thing because parents will more easily access the application of interventions anywhere and anytime. Each parent only needs to download the educational application on the gadget and open it at any time.

Before developing an application or coding, the first step that must be done is the development of the UI/UX so that it has good quality in terms of ease of use, efficiency and user satisfaction. UI/UX development needs in-depth research to optimize the user experience while creating an attractive display. Some of the main influences of the urgency of UI/UX development are that parents are satisfied and happy with the application with the features in the application, users find it easy when using the application, have the best experience when using the application, as well as the application is comfortable to use and the interface is clean from bugs.

Based on this, a UI/UX design is needed to develop an application design for autism intervention education, family intervention. UI/UX design is the right thing before application development so that all components in the application have actual usefulness and are related to the success or achievement of application design goals. Therefore, the researcher wants to conduct research and development with the title " User Interface and User Experience Design of Family Intervention Application for Parents of Children with Autism."

\section{METHOD}

The method used in this research is Design Thinking. Several research steps include empathy, defining ideate, prototype, and testing [11]. The design thinking method is a user-oriented approach to developing creative ideas as problem solving solutions [12]. Solution creation should also be as simple as possible and have meaningful benefits.

\subsection{Empathy}

Empathy is the stage of collecting data related to the problem. Collecting data using online questionnaires and interviews with parents and teachers who teach children with autism. [12] said that the empathy stage is called the understanding stage. This stage is to understand the problems faced by users, such as how they feel, what they understand, and what they order [13].

\subsection{Define}

At this stage, the researcher defines the problems understood from the empathy stage. The result of defining the problem is the emergence of problem points that will be solved in the UI/UX development of family intervention applications. At this stage, it determines user needs as an innovation [13].

\subsection{Ideate}

After defining the problem, the researcher determines the idea that will be the solution to the problem found. Researchers must focus on the problems found so that the UI/UX development is in accordance with the needs and the application is more user friendly and is utilized and needed by potential users, parents of children with autism. At this stage, the need for creative ideas that can answer user needs in solving problems [13]. Researchers create a user flow and sitemap for the results at the ideate stage.

\subsection{Prototype}

This phase is essential because the previous ideas must be visualized. In this phase, there are stages of sketching, designing, modeling, and so on [12]. The prototype is the stage of making UI/UX development designs based on ideas that are used to solve the problems of parents of children with autism barriers. Prototyping starts from low wireframe fidelity, then high fluidity prototype. Prototyping using Figma.

\subsection{Test}

The test phase in this study was carried out with two tests, usability testing and questionnaires. Usability testing has several stages. The first is to determine the evaluator. The evaluator for usability testing is one parent of a child with autism and a teacher who teaches autism. The second stage is to create a usability test task. Then the prospective user performs prototype testing through Maze by performing tasks. This stage is used to verify whether the development has achieved the goals [13]. The stages of usability testing are determining evaluators, making usability tasks, compiling test scripts, carrying out usability tests by trying out application prototypes, analyzing data from usability test results and compiling recommendations for application improvements.

The application prototype experiment was carried out using a maze. Maze is the platform that will be used for online usability testing. This platform provides services to perform usability testing. The prototype is distributed to parents and teachers via a link. Parents and teachers can simulate the flow of application usage by opening the link. 
Next is to provide a usability test aspect questionnaire to prospective users as data analysis. The usability aspects that are compiled include learnability and memorability.

\section{RESULTS AND DISCUSSION}

\subsection{Empathy}

Based on the questionnaire that has been distributed to parents, $11.1 \%$ of parents have never given intervention for their children at home, $100 \%$ of parents find it challenging to provide intervention, then if parents do not know the stages of intervention, $55.6 \%$ of parents search the internet and 44, $4 \%$ asked someone else.

Then $55.56 \%$ of parents never used an intervention guide application at home, and $88.9 \%$ of parents said that they would download a therapy or intervention guide application for autistic children at home.

Then, based on the parental needs questionnaire, it produced data, $66.7 \%$ needed a student therapy needs assessment feature, $44.4 \%$ needed a basic ability therapy guide feature such as sitting quietly and eye contact, $66.67 \%$ needed a social interaction ability therapy guide feature, $83,3 \%$ needed communication therapy guidance, $44.4 \%$ needed sensory processing ability therapy guidance, $50 \%$ needed motor skills therapy guidance, $72.2 \%$ needed behavioral therapy guidance, and $44.4 \%$ needed visual assistance. So it can be concluded that it can be realized that the UI/UX development of educational applications for Family Interventions with several features. There is an assessment of intervention needs, social interaction interventions, communication interventions, and behavioral interventions can be realized.

Furthermore, at the interview stage, the prospective users are three parents. The first parents still do not know that parents can intervene for their children at home while doing daily activities. Second, the problem experienced by parents is that they still have not found an intervention guide that suits their needs. Parents have tried to intervene at home, but do not know the appropriate steps. Third, parents do not have time to provide interventions to their children because parents feel that their children's intervention at home takes a long time.

\subsection{Define}

Based on the defined process, it was found that the main problem is that most of the prospective users still think that implementing interventions at home is challenging to do, so that a solution to this problem is obtained, making mobile educational applications that are designed according to the needs of potential users' problems as an alternative application approach to make it more user friendly and actually utilized by potential users, parents of children with autism. Based on the data obtained, the target prospective users are around 27-53 years old. The define stage uses several processes to map the target potential users as follows:

\subsubsection{User Persona}

In the user persona process, the target users are 2 people, the first is the parent user, and the second is the autistic teacher user. Here are the user personas of each user:

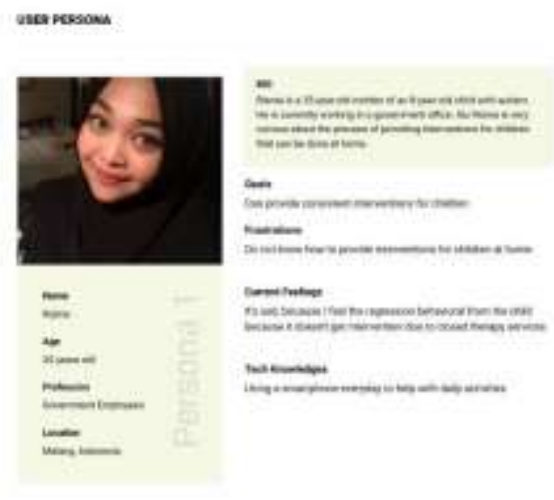

Figure 1 Parent's User Persona

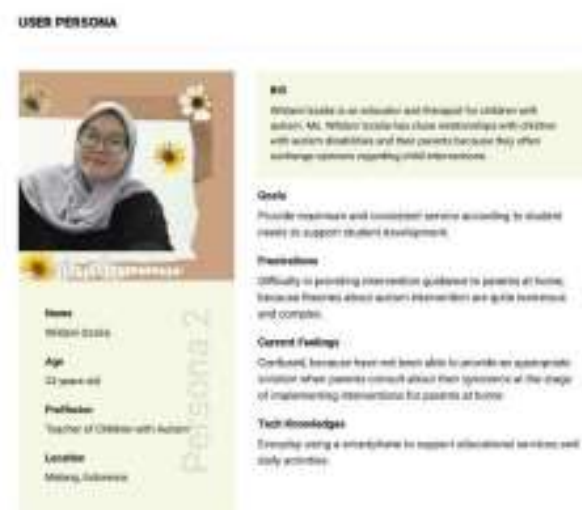

Figure 2 Teacher's User Persona

\subsubsection{User Scenarios}

The next stage is user scenarios. The user scenario consists of the columns "As who?", "I want" to explain user expectations quickly based on frustration with the user persona. Then in the "so that" column, explain the expectations after the solution desired by the user. The last column, namely "scenario", is a story that describes user activities related to the behavior, attitudes, and frustrations of these users 
Table 1. User Scenarios

\begin{tabular}{|c|c|c|c|}
\hline As a... & I want to... & So that... & Scenario \\
\hline Parent & $\begin{array}{l}\text { I want to } \\
\text { provide } \\
\text { consistent } \\
\text { interventions } \\
\text { for my child, } \\
\text { as well as } \\
\text { interventions } \\
\text { that I can do in } \\
\text { my daily life }\end{array}$ & $\begin{array}{l}\text { My child can } \\
\text { improve in } \\
\text { some } \\
\text { aspects of } \\
\text { development } \\
\text { gradually and } \\
\text { little by little. }\end{array}$ & $\begin{array}{l}\text { At 6:40 p.m. on a Monday night, Risma accompanied her son to dinner, } \\
\text { but his son showed disobedient behavior when instructed to sit on the } \\
\text { dining chair for dinner. Risma realizes that children need to be given } \\
\text { consistent interventions, including at home, and not only in therapy, } \\
\text { because habituation at home is also very important. Risma looked for } \\
\text { stages of intervention for children on the internet but did not find an easy } \\
\text { step by step. So, Risma wants a solution so that Risma can find out the } \\
\text { steps for providing interventions for children at home so that she can } \\
\text { provide consistent interventions that are in accordance with the child's } \\
\text { needs. }\end{array}$ \\
\hline $\begin{array}{l}\text { Teache } \\
\text { r of } \\
\text { Childre } \\
\text { n with } \\
\text { Autism }\end{array}$ & $\begin{array}{l}\text { I want parents } \\
\text { to be able to } \\
\text { apply the } \\
\text { intervention } \\
\text { consistently at } \\
\text { home and in } \\
\text { daily activities }\end{array}$ & $\begin{array}{l}\text { I can provide } \\
\text { solutions to } \\
\text { parents } \\
\text { regarding the } \\
\text { application of } \\
\text { interventions } \\
\text { by parents in } \\
\text { daily } \\
\text { activities }\end{array}$ & $\begin{array}{l}\text { At } 11.00 \text { on Thursday afternoon, Wildani had conducted online learning by } \\
\text { video call with several students in her class. However, at the end of the } \\
\text { session, several parents were consulted regarding the development of } \\
\text { children who had setbacks. Parents asked Ms. Wildani for advice } \\
\text { regarding this problem. Mrs. Wildani gave advice that parents should } \\
\text { provide interventions for children at home consistently. Ms. Wildani was } \\
\text { confused about providing guidance to parents in implementing } \\
\text { interventions at home, so Ms. Wildani sent a photo from a book that } \\
\text { contains the stages of implementing the intervention, but the solution is } \\
\text { still not efficient because the theory from the book is still very complex. } \\
\text { Therefore, Wildani wanted a solution to help parents in implementing } \\
\text { interventions for their children at home, so that Mrs. Wildani could rest } \\
\text { easy because her children received consistent interventions. }\end{array}$ \\
\hline
\end{tabular}

\subsubsection{Costumer Journay Map}

At the customer journey map stage, there are several parts such as stages, user actions, user goals, channels, problems, and ideas. The following is the customer journey map of each user persona for the Family Intervention application. Based on the customer journey map of each persona, it is explained that prospective users need a solution in the form of a family intervention application that will be used according to the needs of potential users.

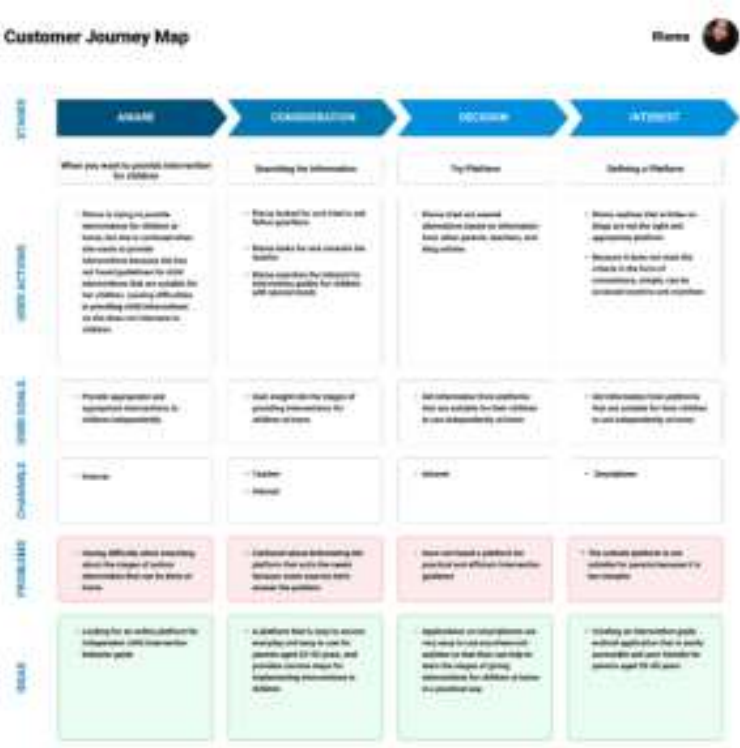

Figure 3 Parent's Customer Journey Map 


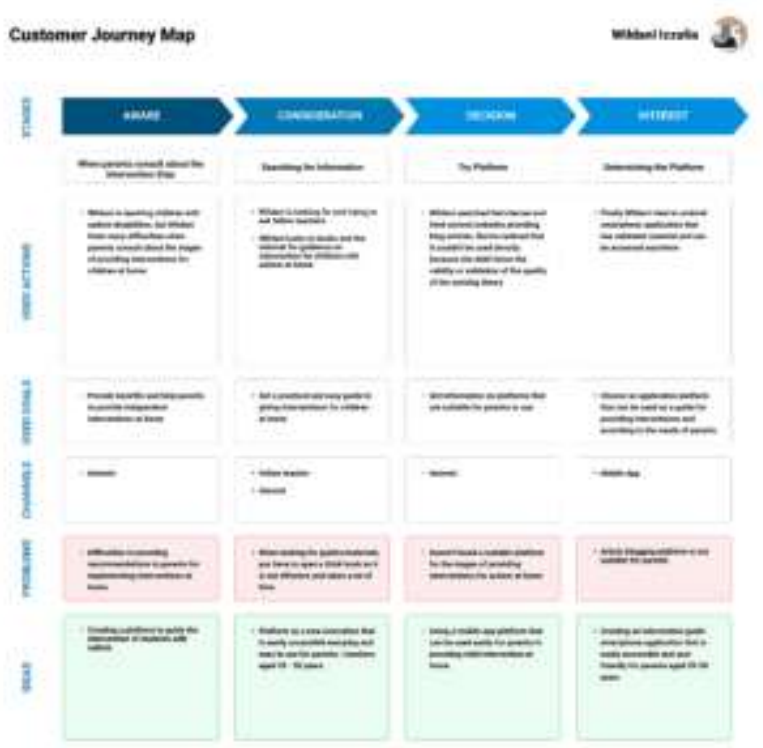

Figure 4 Teacher's Customer Journey Map

\subsection{Ideate}

Through the define stage, the researcher found that parents did not have easy access to learning interventions, and parents did not know the stages or procedures for implementing the intervention. So parents must learn the procedure for providing interventions for children at home step by step. In addition, providing access to guides via cell phones will make it easier for parents because cell phones are always in their hands. So parents can intervene anywhere and anytime by looking at the guide on the cellphone.

UI/UX development of family intervention applications using the integration of the ABA approach. One of the interventions that can be applied at home is the ABA approach. Giving ABA at home with parental involvement is an effective intervention for children with autism barriers [14]. In addition, the ABA program is effective enough to be very effective, bringing significant benefits to several abilities, expressive language skills, intellectual abilities, communication skills, socialization, adaptive behavior, and daily life skills [15]. The ABA approach can also be used to increase sleep hours in children [16], improve children's social skills and reduce children's hyperactive behavior [17], and reduce behavioral problems [18].

The ABA approach is structured to be simple and easy for parents to implement. Before carrying out the intervention stage, parents also fill out an intervention needs assessment to determine the child's intervention needs. At the ideate stage, several processes must be carried out, creating user flows and sitemaps.

\subsubsection{User Flow}

The following is the user flow from the family intervention applications:

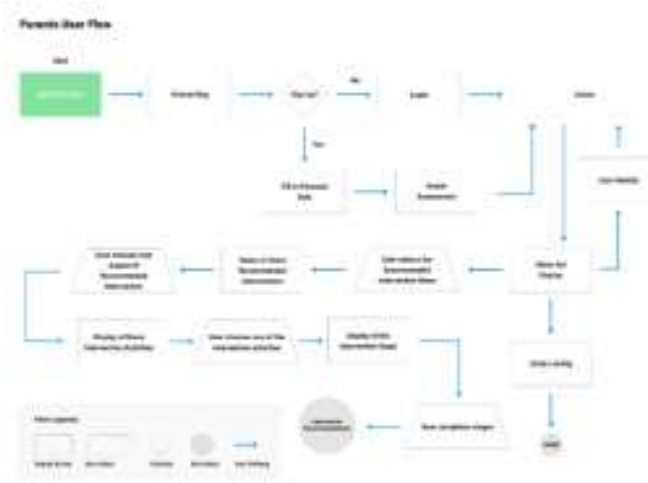

Figure 5 Parent's User Flow

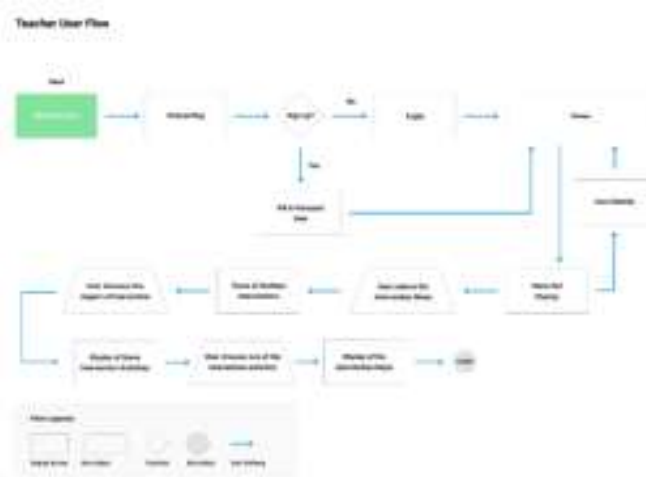

Figure 6 Teacher's User Flow

\subsubsection{Sitemaps}

The sitemap or application framework has the main feature (main feature) and the content of the main feature (Main Content Feature). The main features consist of Onboarding, User Identity, Intervention Needs Assesment, Child's Ability, Intervention Recommendations, and About Us.

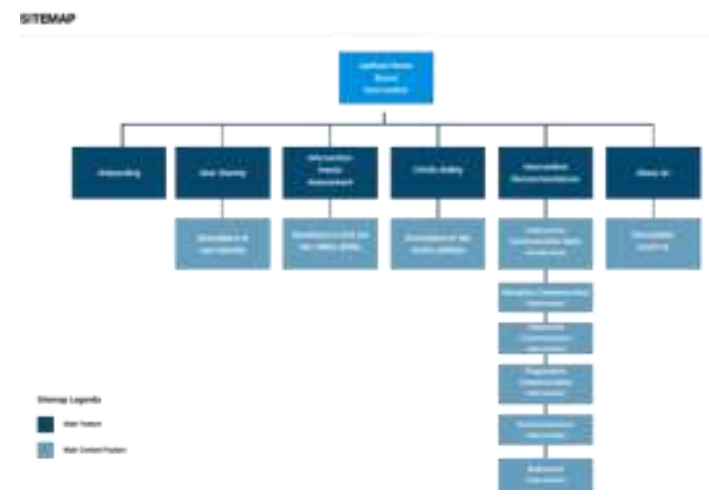

Figure 7 Application's Sitemap 


\subsection{Prototype}

The results are in the form of a low-fidelity and high-fidelity prototype wireframe display in the prototyping process. The prototype design was made using Figma. The low fidelity and high fidelity wireframes shown below are not all because the number of pages limits them.

\subsubsection{Wireframe Low Fidelity}

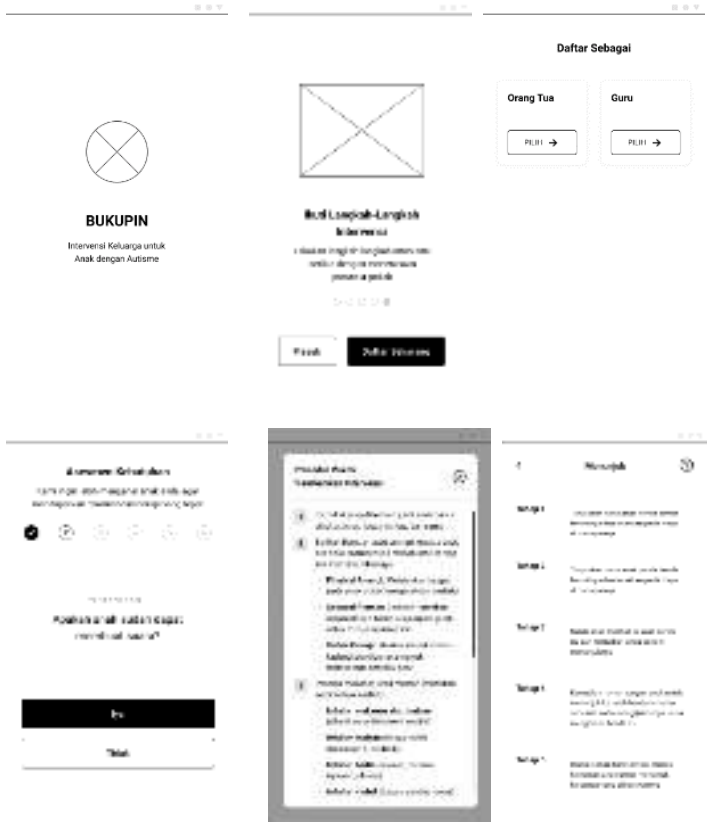

Figure 8 Wireframe Low Fidelity of Family Intervention

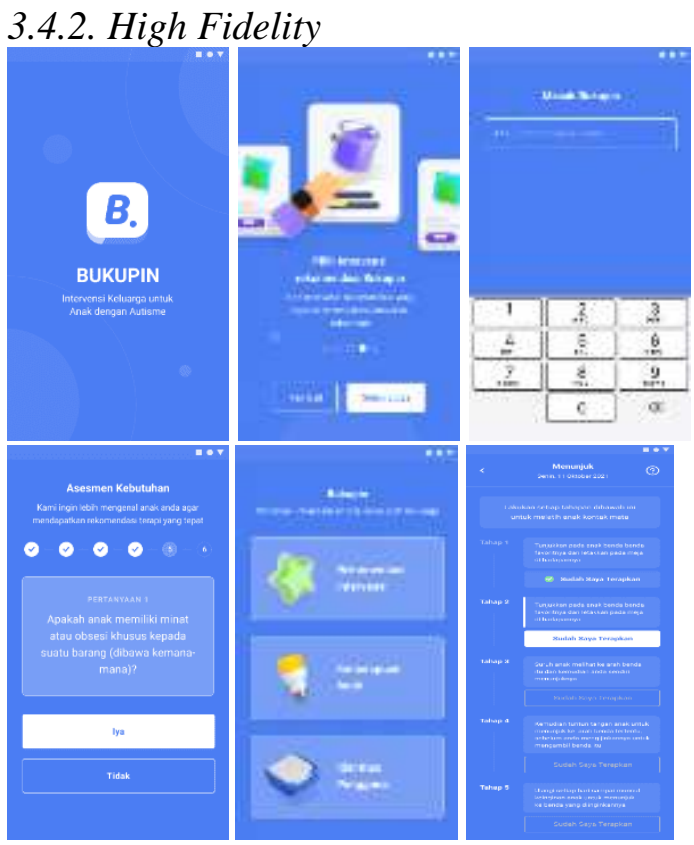

Figure 9 High Fidelity of Family Intervention
The test through usability testing using the Maze platform of parents flow is $96 \%$. There are 14 parents that respond to this maze design. The result of each task of parents flow in figure 10 until figure 15.

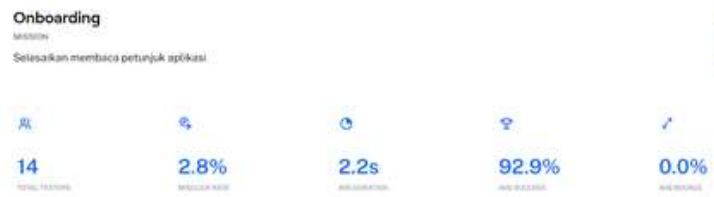

Figure 10 Mission report of onboarding

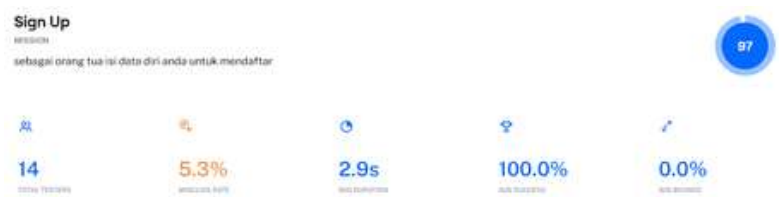

Figure 11 Mission report of sign up

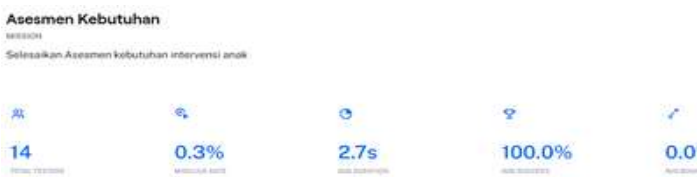

Figure 12 Mission report of needs assessment

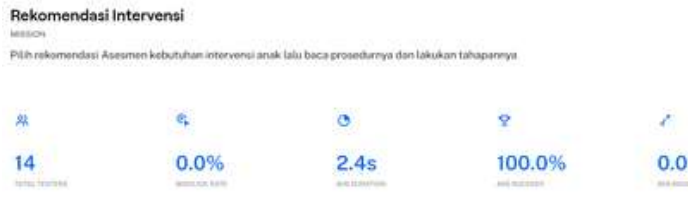

Figure 13 Mission report of needs assessment

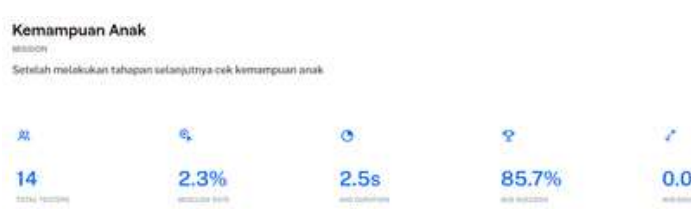

Figure 14 Mission report of child's ability

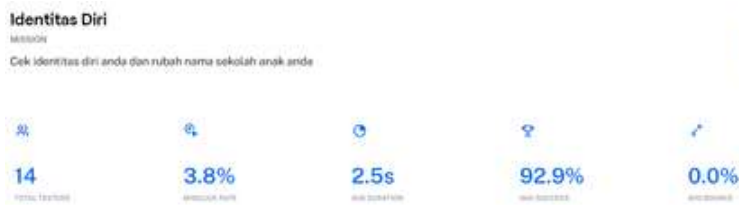

Figure 15 Mission report of personal identity

The test through usability testing using the Maze platform of teacher flow is $98 \%$. The results of onboarding mission is $100 \%$, signup mission is $99 \%$, intervention aspects mission is $96 \%$, and personal identity mission aspects is $96 \%$. There are misclick in intervention aspects 8,33\% and in personal identity $8,33 \%$. More clearly can see figure 16 until figure 19 .

\subsection{Test}




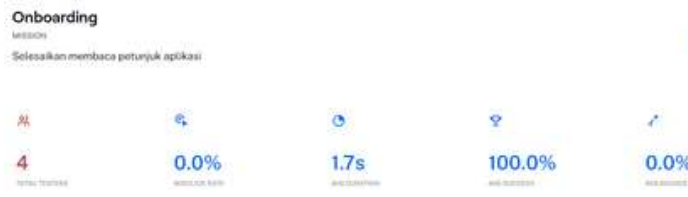

Figure 16 Mission report of onboarding
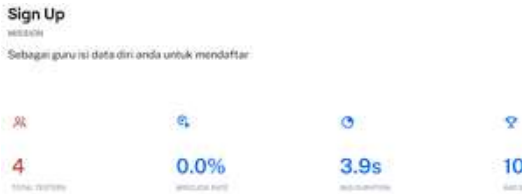

Figure 17 Mission report of signup

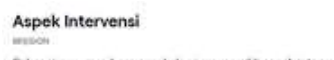

\%.

4

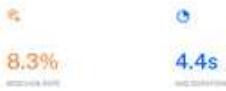

$100.0 \%$
Identitas Diri

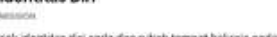

2)

$\begin{array}{lllll}4 & 8.3 \% & 2.5 s & 100.0 \% & 0.0 \%\end{array}$

Figure 19 Mission report of personal identity

Then in data analysis using a usability test questionnaire, the learnability aspect was obtained a value of $90 \%$ and the memorability aspect was obtained a value of $80 \%$.

Figure 18 Mission report of intervention aspects

Table 2. Questionnaire for Parent

\begin{tabular}{|c|c|c|c|c|c|}
\hline No & Questions & R1 & $\mathbf{R 2}$ & Yes $(\%)$ & No $(\%)$ \\
\hline \multicolumn{6}{|c|}{ Learnability } \\
\hline 1 & Is it easy to complete app onboarding? & 1 & 1 & 100 & 0 \\
\hline 2 & Is user signup easy to do? & 1 & 1 & 100 & 0 \\
\hline 3 & Is it easy to choose the intervention menu to do? & 1 & 1 & 100 & 0 \\
\hline 4 & Is it easy to see the child's ability menu? & 1 & 1 & 100 & 0 \\
\hline 5 & Is it easy to read the recorded identity menu? & 0 & 1 & 50 & 50 \\
\hline \multicolumn{4}{|c|}{ Total } & 90 & 10 \\
\hline \multicolumn{6}{|c|}{ Memorability } \\
\hline 6 & $\begin{array}{l}\text { Are the questions on the application easy to } \\
\text { understand? }\end{array}$ & 0 & 1 & 50 & 50 \\
\hline 7 & $\begin{array}{l}\text { Are the displays and menus on the Family Intervention } \\
\text { page easy to remember? }\end{array}$ & 1 & 1 & 100 & 0 \\
\hline 8 & $\begin{array}{l}\text { Are the colors in the Family Intervention application } \\
\text { easy to see \& the display not boring? }\end{array}$ & 1 & 1 & 100 & 0 \\
\hline 9 & $\begin{array}{l}\text { Is the information on the key hint features clear } \\
\text { enough? }\end{array}$ & 1 & 1 & 100 & 0 \\
\hline 10 & Is the set of available intervention types clear enough? & 0 & 1 & 50 & 50 \\
\hline \multicolumn{4}{|c|}{ Total } & 80 & 20 \\
\hline
\end{tabular}

\section{CONCLUSION}

Parents' perceptions of the difficulty of implementing interventions at home must be changed. Implementation of interventions at home can be integrated with simple daily activities. Based on this, educational media is needed to make it easier for families to carry out interventions at home. The first step that must be taken is the development of UI/UX so that it has good quality in terms of ease of use, efficiency and user satisfaction, in accordance with the needs of potential users' problems as an alternative application approach to make it more user friendly and 
used by potential users, parents of autistic children. Testing through usability testing on parents flow using the Maze platform obtained $96 \%$ results, and teachers flow obtained $98 \%$. Then in data analysis using usability test questionnaires, the learnability aspect was obtained $90 \%$, and the memorability aspect was obtained $80 \%$. The whole test showed excellent and successful results so that the prototype can be continued on the implementation of the application.

\section{AUTHORS' CONTRIBUTIONS}

All authors conceived and designed this study. All authors contributed to the process of revising the manuscript, and at the end all authors have approved the final version of this manuscript.

\section{ACKNOWLEDGMENTS}

We acknowledge the support received from people who were very helpful in the completion of this research, in particular the parents of children with autism and teachers who actively contributed to filling out the questionnaire and providing suggestions.

\section{REFERENCES}

[1] F. Mangunsong, Psikologi dan Pendidikan Anak Berkebutuhan Khusus, 1st ed. Depok: Lembaga Pengembangan Sarana Pengukuran dan Pendidikan Psikologi, 2009.

[2] J. Martin, G \& Pear, Behavior Modification: What it is and How to do it. United States of America: Pearson Education, Inc, 2015.

[3] A. N. Ansori, "Pengaruh Covid-19 terhadap Keluarga dengan Anak Autis menurut Survei," Liputan6,

2020. https://www.liputan6.com/disabilitas/read/4228 290/pengaruh-covid-19-terhadap-keluargadengan-anak-autis-menurut-survei.

[4] M. Colizzi, E. Sironi, F. Antonini, M. L. Ciceri, C. Bovo, and L. Zoccante, "Psychosocial and behavioral impact of COVID-19 in autism spectrum disorder: An online parent survey," Brain Sci., vol. 10, no. 6, pp. 1-14, 2020, doi: 10.3390/brainsci10060341.

[5] J. Manning, J. Billian, J. Matson, C. Allen, and N. Soares, "Perceptions of Families of Individuals with Autism Spectrum Disorder during the COVID-19 Crisis," J. Autism Dev. Disord., vol. 51, no. 8, pp. 2920-2928, 2021, doi: 10.1007/s10803-020-04760-5.

[6] Handojo, Autisma: Petunjuk Praktis dan Pedoman Materi untuk Mengajar Anak Normal, Autis, dan Perilaku Lain. Jakarta Barat: PT. Bhuana Ilmu Populer, 2003.
E. R. S. Malucelli, S. A. Antoniuk, and N. O. Carvalho, "The effectiveness of early parental coaching in the autism spectrum disorder," $J$. Pediatr. (Rio. J)., no. $\mathrm{xx}, \quad 2020$, doi: 10.1016/j.jped.2020.09.004.

[8] H. Il Park, H. Y. Park, E. Yoo, A. Han, and G. Galeoto, "Impact of Family-Centered Early Intervention in Infants with Autism Spectrum Disorder: A Single-Subject Design," Occup. Ther. Int., vol. 2020, 2020, doi: $10.1155 / 2020 / 1427169$.

[9] M. Rutherford, A. Singh-Roy, R. Rush, D. McCartney, A. O'Hare, and K. Forsyth, "Parent focused interventions for older children or adults with ASD and parent wellbeing outcomes: A systematic review with metaanalysis," Res. Autism Spectr. Disord., vol. 68, p. 101450, 2019, doi: 10.1016/j.rasd.2019.101450.

[10] S. J. Gentles, D. B. Nicholas, S. M. Jack, K. A. McKibbon, and P. Szatmari, "Coming to understand the child has autism: A process illustrating parents' evolving readiness for engaging in care," Autism, vol. 24, no. 2, pp. 470-483, 2020, doi: $10.1177 / 1362361319874647$.

[11] H. Plattner, C. Meinel, and U. Weinberg, Design Thinking. Munich: mv-verlag, 2009.

[12] C. M. Roterberg, Handbook of Design Thinking: Tips \& Tools for How to Design Thinking. Amazon Digital Services LLC, 2018.

[13] S. Gibbons, "Design Thinking 101," Nielsen Norman Group, 2016 https://www.nngroup.com/articles/designthinking/ (accessed Oct. 10, 2021).

[14] Y. Liao, K. Dillenburger, W. He, Y. Xu, and H. Cai, "A Systematic Review of Applied Behavior Analytic Interventions for Children with Autism in Mainland China," Rev. J. Autism Dev. Disord., 2020, doi: 10.1007/s40489-020-00196$\mathrm{W}$.

[15] M. K. Makrygianni, A. Gena, S. Katoudi, and P. Galanis, "The effectiveness of applied behavior analytic interventions for children with Autism Spectrum Disorder: A meta-analytic study," Res. Autism Spectr. Disord., vol. 51, no. March, pp. 18-31, 2018, doi: 10.1016/j.rasd.2018.03.006.

[16] E. Delemere and K. Dounavi, "ParentImplemented Bedtime Fading and Positive Routines for Children with Autism Spectrum Disorders," J. Autism Dev. Disord., vol. 48, no. 4, pp. 1002-1019, 2018, doi: 10.1007/s10803017-3398-4 
[17] J. Pennefather, M. Hieneman, T. J. Raulston, and N. Caraway, "Evaluation of an online training program to improve family routines, parental well-being, and the behavior of children with autism," Res. Autism Spectr. Disord., vol. 54, pp. 21-26, 2018, doi: 10.1016/j.rasd.2018.06.006.

[18] S. Lindgren et al., "Telehealth and Autism: Treating challenging behavior at lower cost," Pediatrics, vol. 137, no. February 2016, pp. S167-S175, 2016, doi: 10.1542/peds.201528510. 